\title{
MICE- MASA DEPAN BISNIS PARIWISATA INDONESIA
}

\author{
Chusnu Syarifa Diah Kusuma \\ Fakultas Ekonomi, Universitas Negeri Yogyakarta, Indonesia \\ chusnu@uny.ac.id
}

\begin{abstract}
Abstrak: MICE - Masa Depan Bisnis Pariwisata Indonesia. MICE (Meeting, Incentive, Conference, Exhibition) adalah terobosan baru untuk kemajuan pariwisata Indonesia karena dinilai memilki keuntungan 7 kali lipat lebih besar dari leisure tourism. Dampak utama adanya bisnis MICE di Indonesia adalah semakin meningkatnya kesejahteraan masyarakat dan citra pariwisata di daerah destinasi MICE. Potensi MICE Indonesia terlihat dari banyaknya event besar bertaraf internasional yang sering menunjuk Indonesia sebagai tuan rumah, selain itu Indonesia memiliki sumber daya manusia $M I C E$ yang profesional, infrastruktur yang berkualitas, sarana dan prasarana akomodasi MICE yang cukup memadai.
\end{abstract}

Kata kunci : MICE, Pariwisata

\begin{abstract}
MICE - The Future of Indonesia's Tourism Business. MICE (Meeting, Incentive, Conference, Exhibition) is a new innovation in tourism field for the advancement of Indonesian tourism because it has profit 7 times bigger than leisure tourism. The potential of Indonesian MICE can be seen from the many large international events that often designate Indonesia as the host, besides that Indonesia has professional MICE Human Resources, infrastructure, and international accommodation.
\end{abstract}

Keywords : MICE, Tourism

\section{PENDAHULUAN}

Pencapaian Indonesia dalam pengembangan pariwisata memang sudah menuai banyak pujian dan apresiasi dari dunia internasional. Apresiasi atau pencapaian Indonesia dalam mengembangkan pariwisata dapat dilihat dari informasi yang dirilis oleh Lonely Planet yang merupakan buku panduan perjalanan dan penerbit media digital terbesar di dunia, Lonely Planet edisi 2018 merilis bahwa Indonesia ditempatkan pada peringkat ke-7 dari 10 teratas sebagai destinasi wisata favorit dan pariwisata terbaik di dunia. Informasi tersebut memang bertolak belakang dengan informasi yang dirilis oleh The Travel and Tourism Competitiveness Index (TTCI) yang dikeluarkan oleh United Nation World Tourism Organization (UNWTO) yang menyatakan bahwa untuk peringkat kunjungan wisatawan asing Indonesia di tahun 2017 berada di peringkat ke - 43 dunia dan peringkat ke-10 se Asia Pasifik. Peringkat tersebut masih cukup jauh dibandingkan dengan negara tetangga kita yaitu Thailand berada di peringkat kedua se Asia- Pasifik dan Malaysia yang berada di posisi kelima se-Asia Pasifik. Sementara itu prestasi yang tak kalah membanggakan bagi Indonesia di sektor pariwisata dirilis oleh Global Muslim Travel Index (GMTI) 2019 yang menyatakan bahwa 
Indonesia telah berhasil sebagai negara dengan destinasi halal (halal tourism) terbaik pertama di dunia

Berdasarkan informasi tentang pencapaian prestasi pariwisata Indonesia tersebut dapat dikatakan bahwa industri pariwisata di Indonesia saat ini sedang mengalami perkembangan yang sangat pesat dan sesuai dengan arahan Menteri Pariwisata Arief Yahya, bahwa Kementerian Pariwisata mencanangkan target kunjungan wisatawan sebanyak 20 juta kunjungan wisatawan pada tahun 2019. Pariwisata telah menjadikan salah satu komoditas yang digunakan untuk menggenjot pendapatan devisa negara. Oleh karena itu, perlu adanya perbaikan sarana dan prasarana pariwisata serta adanya inovasi dibidang pariwisata.

Pengembangan kualitas pariwisata Indonesia diharapkan semakin baik dari tahun ke tahun maka dunia pariwisata tak terlepas dari industri yang berperan penting dalam pelaksanaan dan perkembangan pariwisata. Industri pariwisata adalah kumpulan usaha pariwisata yang saling terkait dalam rangka menghasilkan barang dan atau / jasa bagi pemenuhan kebutuhan wisatawan dalam penyelenggaraan pariwisata. Indonesia adalah negara yang berpotensial dalam pengembangan industri pariwisata, selain alam dan budaya yang menjadi pusat perhatian dunia. Sumber Daya Manusia (SDM) yang mumpuni dalam bidang pariwisata, menjadikan nilai tambah dalam pengembangan industri di Indonesia.

Industri kepariwisataan di Indonesia tentunya tidak terlepas dari mata rantai sektor usaha jasa MICE (Meetings, Incentives, Conferences, Exhibitions). Pada era globalisasi dan semakin eksisnya Revolusi Industri 4.0 saat ini terutama didukung dengan kemajuan teknologi, pengetahuan serta persaingan bisnis yang menyebabkan banyaknya diselenggarakan berbagai pertemuan, perundingan baik di skala nasional dan international, sehingga prospek Industri MICE semakin berkembang. Kegiatan MICE selalu melibatkan banyak sektor dan banyak pihak sehingga menimbulkan pengaruh ekonomi ganda yang menguntungkan banyak pihak. Beberapa pihak potensial yang banyak mendapatkan keuntungan dari sektor MICE yaitu Event Organizer (EO), Professional Conference Organizer (PCO), Percetakan, Perusahaan Souvenir, Perhotelan, Biro Perjalanan Wisata, Transportasi, Usaha Kecil dan Menengah (UKM).

Berdasarkan data dari International Congress and Convention Association (ICCA) tahun 2018, jumlah participant bagi Negara Indonesia untuk melaksanakan business travel sebanyak 44.445 participant dan hal ini membuat Indonesia berada di peringkat 34 dunia, jumlah ini ternyata masih kalah saing dibandingkan dengan negara Asia Tenggara lainnya seperti Thailand diperingkat 23 dunia dengan jumlah participant sebanyak 70.892, Singapura berada di peringat ke 24 dunia dengan jumlah participant sebanyak 69.261 dan Malaysia yang berada diperingkat ke-26 dunia dengan jumlah participant sebanyak 62.271 peserta 
Sementara itu dari sumber yang sama disebutkan pula bahwa, Indonesia juga memiliki beberapa kota favorit di dunia untuk menyelenggarakan event international meetings diantaranya adalah Bali, Yogyakarta dan Jakarta. Berdasarkan data dari ICCA tahun 2018, Bali berada di peringkat ke - 15 se-Asia Pasifik dengan jumlah penyelenggaraan event meetings sebanyak 40 event, diikuti oleh Yogyakarta yang berada di peringkat 23 se-Asia Pasifik dengan jumlah penyelenggaraan event meetings sebanyak 26 kali, lalu terakhir diikuti oleh Jakarta yang berada diperingkat ke-27 dengan jumlah penyelenggaraan sebanyak 23 meetings events.

Pada dasarnya Indonesia memiliki banyak potensi pariwisata dan Sumber Daya Manusia yang bisa dikembangkan untuk dapat menyelenggarakan industri MICE yang modern bahkan Indonesia berpeluang untuk menjadi "Surga MICE Dunia", akan tetapi dalam pengembangan industri MICE di Indonesia masih menghadapi beberapa kendala diantaranya: (1) Masih rendahnya awareness destinasi akan pentingnya MICE dan perlunya dilakukan promosi MICE; (2) Kurangnya database MICE yang online and komprehensif; (3) Masih terbatasnya kemudahan dan fasilitas pendukung kegiatan MICE khususnya aksesibilitas (penerbangan langsung), insentif bagi kegiatan MICE (barang pameran dan souvenir untuk peserta insentif tour masuk dalam kategori impor).

Oleh karena itu, dibutuhkan adanya dukungan infrastruktur dengan kualitas yang bagus menjadi hal yang sangat penting diantaranya akses udara, jalan atau rel kereta api, convention center dengan kualitas bagus, hotel antara bintang tiga hingga bintang lima, destinasi yang atraktif dan memiliki nilai tambah, pemasaran yang baik, dan professional conference organizer (PCO) lokal yang ahli di bidangnya. Disisi lain perlunya agresifitas dari para penyedia jasa MICE di Indonesia untuk menarik pasar luar negeri. Dalam industri jasa ini kita tidak cukup hanya dengan pro-aktif merebut pasar MICE, tapi harus agresif dengan mengerahkan semua sumberdaya untuk melakukan lobi serta upaya memenangkan bidding internasional yang dilakukan pelaku bisnis pariwisata/ PCO bersama pemerintah, sehingga dengan memperhatikan beberapa aspek tersebut Indonesia siap untuk menjadi Negara tujuan utama dalam penyelenggaraan MICE di dunia.

Pengertian MICE adalah akronim dari meetings, incentives, conferences and exhibitions. Wisata MICE merupakan salah satu sektor dalam industri pariwisata yang berkembang sangat pesat. Kegiatan wisata MICE melibatkan berbagai sektor seperti sektor transportasi, perjalanan, rekreasi, akomodasi, makanan dan minuman, tempat penyelenggaraan acara, teknologi informasi, perdagangan dan keuangan sehingga wisata MICE dapat digambarkan sebagai industri multi aset. Di banyak daerah tujuan wisata, kegiatan MICE dikategorikan di bawah payung industri event (Dwyer dan Mistilis: 2000). 
Yoeti (2000) menyatakan bahwa MICE merupakan suatu rangkaian kegiatan, dimana pengusaha dan profesional berkumpul pada suatu tempat yang terkondisikan oleh suatu permasalahan, pembahasan dan kepentingan yang sama.

Menurut CIC (2011), “Conferences merupakan elemen ketiga dari wisata MICE yang dapat diartikan sebagai suatu pertemuan partisipatif yang dirancang terutama untuk tujuan diskusi, mencari dan berbagi informasi, memecahkan masalah dan konsultasi. Conferences biasanya memiliki keterbatasan waktu dan memiliki tujuan khusus. Conference mirip dengan meeting di mana suatu acara conference melibatkan 10 orang atau lebih selama minimal empat jam dalam satu hari atau lebih dan kegiatan conference diadakan di luar perusahaan itu sendiri”.

Menurut Montgomery dan Strick (1995), “istilah exhibitions digunakan untuk menggambarkan event yang dirancang untuk mempertemukan pemasok produk, peralatan industri dan jasa di suatu tempat di mana para peserta dapat mendemonstrasikan dan mempromosikan produk dan jasa yang mereka tawarkan

Menurut Pendit (1999) yang dikutip oleh Andiani (2014:7) dalam buku berjudul Pengelolaan Wisata Konvensi bahwa Usaha jasa konvensi, perjalanan insentif, dan pameran merupakan usaha dengan kegiatan memberi jasa pelayanan bagi suatu pertemuan sekelompok orang (negarawan, usahawan, cendekiawan dan sebagainya) untuk membahas masalah-masalah yang berkaitan dengan kepentingan bersama. Pada umumnya kegiatan konvensi berkaitan dengan usaha pariwisata lain, seperti transportasi, akomodasi, hibitran (entertainment), perjalanan pra- dan pasca-konferensi (preand post- conference tours).

Pengertian Pariwisata menurut Undang - Undang Nomor 10 Tahun 2009 tentnag Kepariwisataan, Pariwisata adalah "Berbagai macam kegiatan wisata dan didukung dengan fasilitas serta layanan yang disediakan masyarakat setempat, sesama wisatawan, pemerintah, pemerintah daerah dan pengusaha. Menurut United Nation World Tourism Organization (UNWTO), pariwisata adalah kegiatan manusia yang melakukan perjalanan ke dan tinggal di daerah tujuan di luar lingkungan kesehariannya.

Berdasarkan beberapa pengertian tersebut, pariwisata adalah perjalanan yang dilakukan oleh seseorang dalam jangka waktu tertentu dari suatu tempat ke tempat lain dengan melakukan perencanaan sebelumnya dengan tujuan untuk rekreasi atau untuk suatu kepentingan sehingga keinginannya dapat terpenuhi. Pariwisata dapat diartikan juga sebagai suatu perjalanan dari suatu tempat ke tempat lain untuk rekreasi lalu kembali ke tempat semula. 


\section{PEMBAHASAN}

\section{Potensi Pengembangan Bisnis MICE di Indonesia}

Pengembangan industri atau bisnis pariwisata MICE perlu untuk memahami kembali persyaratan usaha pariwisata seperti yang terdapat dalam Undang-Undang Republik Indonesia No. 10 Tahun 2009 pasal 14 ayat 1 tentang kepariwisataan yang meliputi: daya tarik wisata, kawasan pariwisata, jasa transportasi wisata, jasa perjalanan wisata, jasa makanan dan minuman, penyediaan akomodasi, penyelenggaraan kegiatan hiburan dan rekreasi, penyelenggaraan pertemuan, perjalanan insentif, konferensi dan pameran, jasa informasi pariwisata, jasa konsultan pariwisata, jasa pramuwisata, wisata tirta dan spa. Oleh karena itu aspek dalam undang - undang tersebut wajib dipenuhi untuk mengambangkan wisata MICE di Indonesia. Untuk semakin memperluas atau memvariasikan pilihan lokasi penyelenggaraan MICE di Indonesia sekaligus untuk pemerataan pendapatan dan pembangunan, maka pihak pemerintah telah menetapkan 10 kota utama dan 3 kota potensial tujuan MICE di Indonesia. 10 kota utama tersebut adalah Medan, Padang/ Bukit Tinggi, Batam, Jakarta, Bandung, Yogyakarta, Surabaya, Bali, Makasar dan Manado. Sedangkan tiga kota potensial adalah Palembang, Lombok dan Balikpapan. Akan tetapi pengembangan Industri MICE tidak hanya terbatas pada kota-kota tersebut melainkan semua kota di Indonsia. Peran Pemerintah daerah memang sangat penting dalam mengembangkan industri MICE. Dengan perkembangan yang agresif dalam bidang perhotelan dewasa ini, pada umumnya setiap ibukota provinsi di Indonesia mampu menyelenggarakan kegiatan MICE berskala nasional bahkan internasional

\section{Aksesibilitas}

Untuk mempermudah wisatawan dalam mencapai daerah tujuan wisata, perlu diperhatikan adanya unsur aksesibilitas yang memadai yaitu dengan memberikan sarana dan prasarana transportasi baik berupa penyediaan kendaraan umum, fasilitas bandara, pelabuhan, stasiun kereta api dan terminal yang memiliki standar internasional serta kualitas jalan yang baik dan jarak tempuh yang singkat untuk mempermudah wisatawan dalam menjangkau lokasi tertentu dengan cepat dan nyaman

Pada tahun 2014 jumlah pelabuhan penyeberangan di Indonesia sejumlah 237 unit, tahun 2015 sejumlah 261 unit, tahun 2016 sejumlah 266 unit, tahun 2017 sebanyak 276 unit serta pada tahun 2018 jumlah pelabuhan penyeberangan diseluruh Indonesia telah mencapai 283 unit. Berdasarkan data tersebut, pertumbuhan rata - rata pertahun dari tahun 2014 - 2018 untuk jumlah Dermaga Penyeberangan mengalami peningkatan sebesar $4,58 \%$.

Sementara itu berdasarkan data statistik dari Laporan Statistik Perhubungan/Transportation Statistics, untuk jumlah Terminal Bus Indonesia Tipe A mengalami penurunan sebesar 6,06\% dari tahun 2014 - 2018. jumlah terminal bus Indonesia tahun 2014 sebanyak 143 unit, tahun 2015 
sebanyak 143 unit, tahun 2016 sebanyak 143 unit, tahun 2017 sebanyak 107 unit dan update terakhir pada tahun 2018 jumlah Terminal Bus Tipe A Indonesia hanya bertambah satu unit menjadi 108 unit.

Sementara itu dari sumber yang sama dijelaskan bahwa untuk transportasi laut, jumlah armada angkutan laut Indonesia pada sejak tahun 2014 hingga tahun 2018 terus mengalami peningkatan untuk mempermudah akses pengiriman barang serta transportasi penumpang dari satu pulau menuju kepulau lainnya. Pada tahun 2014 jumlah armada kapal di Indonesia yang teridiri dari kapal nasional, charter asing dan keagenan asing sebanyak 18.771 unit, tahun 2015 sebanyak 20.608 unit, tahun 2016 sebanyak 33.396 unit, tahun 2017 sebanyak 33.188 unit dan pada tahun 2018 sebanyak 33.239 unit.

Fasilitas bandara besar yang dimiliki oleh Indonesia juga menjadi perhatian utama pemerintah untuk dikembangkan sebagai negara yang semakin modern dan bertaraf internasional demi kenyamanan penumpang domestik dan mancanegara. Berdasarkan informasi yang dilansir dari website PT. Angkasa Pura I dan II terdata bahwa Indonesia memiliki fasilitas bandara kelas internasional sebanyak 30 bandara yang tersebar diseluruh Indonesia. Tentunya dengan adanya bandara yang berkelas dapat mencerminkan bahwa Indonesia memang serius untuk menjadi negara penyedia layanan transportasi wisata terbaik di dunia.

Berdasarkan data dari Statistik Perhubungan: Kementerian Perhubungan Indonesia Tahun 2018, jumlah sarana kereta api yang di miliki oleh PT. Kereta Api Indonesia saat ini terdata sebanyak 12.334 jenis kereta api yang terdiri dari rangkaian lokomotif dan gerbong. Panjang lintasan rel kereta api yang terdata di seluruh Indonesia pada tahun 2018 adalah sepanjang 6.601,634 kilometer. Jumlah persinyalan elektrik kereta api yang tersebar dari Jawa hingga Sumatera adalah sebanyak 280 unit di tahun 2018. Sementara itu untuk jumlah stasiun kereta api di seluruh Indonesia selalu mengalami peningkatan.

Berdasarkan informasi tersebut, dapat disumpulkan bahwa pada dasarnya Indonesia telah memiliki sarana dan prasarana transportasi umum yang cukup memadai dan berkualitas dibeberapa kota besar di Indonesia untuk menunjang industri pariwisata dan pelayanan wisata MICE di Indonesia.

\section{Jasa Perjalanan Wisata Indonesia}

Setelah kita mengetahui beberapa informasi tentang perkembangan transportasi penyedia perjalanan wisata bagi para wisatawan lokal maupun mancanegara, aspek selanjutnya yang perlu untuk diperhatikan adalah Indonesia harus memiliki banyak usaha penyedia perjalanan wisata (itienerary) yang berkualitas dan sangat kredibel dalam menyediakan jasa perjalanan wisata terbaik bagi wisatawan terutama wisatawan mancanegara 


\section{Jasa Penyedia Makanan dan Minuman/Food and Beverage}

Aspek selanjutnya yang sangat penting bagi Indonesia apabila akan menyelenggarakan atau merencanakan event MICE tentunya adalah faktor konsumsi baik itu makanan dan minuman. Setiap penyelenggaraan event MICE tentunya akan menghadirkan beberapa tamu penting dari berbagai negara dan juga akan didatangi oleh peserta delegasi dari masing - masing negara, mereka semua tentunya memiliki selera makanan yang berbeda - beda satu sama lain. Oleh karena itu, pihak penyelenggara perlu cermat dan berhati - hati dalam menyajikan makanan dan muinuman kepada tamu negara yang hadir dengan mendata kembali makanan khas dari masing - masing peserta delegasi, melakukan pendataan terhadap alergi makanan atau makanan yang tidak boleh dikonsumsi, melakukan konsultasi dengan ahli gizi dan ahli bidang makanan terkait dengan menu yang akan dipilih.

\section{Akomodasi}

Penyelenggaraan MICE memang dilakukan secara rutin namun, untuk penyelenggaraannya tidak selalu hanya disatu negara saja, melainkan diselenggarakan secara bergantian dari satu negara lalu ke negara yang lain sesuai dengan anggota delegasi negara dari organisasi internasional tersebut yang telah dinilai siap untuk mengadakan event pertemuan selanjutnya, sehingga event internasional tersebut dianggap sebagai suatu hal yang langka bagi masing - masing negara dan sangat prestisuis bagi negara yang ditunjuk untuk menyelenggarakannya dan tentunya dalam agenda MICE tersebut memiliki banyak kegiatan penting untuk membahas isu - isu tertentu demi kemajuan antar bangsa. Oleh karena itu, kegiatan MICE biasanya tidak hanya diselenggarakan hanya dalam jangka waktu satu atau dua hari saja namun biasanya diselenggarakan rata - rata hingga satu minggu lamanya sehingga masing - masing negara perlu untuk mempersiapkan akomodasi terbaiknya bagi perwakilan setiap tamu kenegaraan. Untuk mendukung kemudahan dan kenyamanan pelaksanaan MICE di Indonesia perlu untuk tersedianya akomodasi yang memadai seperti fasilitas hotel dan penginapan yang berkualitas.

\section{Penyelenggaraan Hiburan dan Rekreasi}

Indonesia sebagai negara yang pernah menjadi tuan rumah penyelenggaraan beberapa event internasional tentunya sudah sangat paham bagaimana caranya untuk menyediakan beberapa fasilitas hiburan atau atraksi wisata bagi para tamu kenegaraan karena Indonesia memiliki berbagai macam destinasi wisata yang menarik di seluruh provinsi dan masing - masing telah memiliki baik berupa wisata alam, wisata belanja, wisata sejarah dan edukasi, wisata keluarga, wisata budaya, wisata kekinian, wisata kuliner dan masih banyak wisata lain. Untuk menyikapi hal tersebut, Indonesia sebagai negara penyelenggara dan pihak manajemen event organizer yang ditunjuk harus segera mendesain paket wisata dan hiburan yang menarik bagi para tamu kenegaraan sekaligus 
untuk memperkenalkan kekayaan Indonesia di mata dunia. Paket wisata tersebut dapat berupa wisata ke lokasi bersejarah di Indonesia, wisata alam yang ada di lokasi sekitar kota penyelenggaraan, terdapat jadwal atraksi budaya dan seni masyarakat lokal yang bisa disuguhkan kepada tamu kenegaraan, serta berkeliling ke lokasi industri oleh - oleh atau kerajinan tangan dari masyarakat lokal dengan adanya aktifitas MICE tersebut, tentunya akan turut mendongkrak perekonomian masyarakat sekitar dan membuat lokasi yang dikunjungi semakin dikenal di mata dunia.

\section{Sumber Daya Manusia Pengelola Jasa Pariwisata dan MICE}

Sumber daya manusia yang dimiliki oleh Indonesia dibidang pariwiata sangat memadai dan tersebar di beberapa subsektor pariwisata. Untuk event internasional seperti MICE tentunya Indonesia telah memiliki banyak usaha pariwisata yang telah tergabung kedalam organisasi masing - masing. Organisasi wisata yang akan berkaitan langsung dengan penyelenggaraan event internasional seperti MICE diantaranya adalah Association of Indonesian Tour and Travel Agency (ASITA), Himpunan Pramuwisata Indonesia (HPI), Perhimpunan Hotel dan Restoran Indonesia (PHRI), Asosiasi Perusahaan Penyelenggara Pameran dan Konvensi Indonesia (ASPERAPI).

\section{Jasa Penyedia Perjalanan Wisata}

Permintaan terhadap usaha perjalanan wisata di Indonesia selalu mengalami peningkatan setiap tahunnya baik dari wisatawan lokal maupun mancanegara, untuk memenuhi permintaan tersebut, maka pihak manajemen dari ASITA terus mempersiapkan dengan baik seluruh sumber daya yang dimilikinya. Berdasarkan data yang dikutip dari website https://www.asita.id saat ini ASITA telah memiliki 34 Dewan Pengurus Daerah (DPD) tingkat provinsi yang telah tersebar di seluruh Indonesia, lebih dari 1,2 juta staf, 75 ribu lebih partner kerjasama baik tingkat nasional maupun internasional serta telah memiliki anggota yang terdaftar sebanyak 4.893 Usaha Perjalanan Wisata (UPW) yang tersebar di seluruh provinsi yang ada di Indonesia.

\section{Jasa Penyedia Pramuwisata Indonesia}

Indonesia memiliki banyak sekali tenaga pramuwisata yang sangat berkompeten di bidangnya, berdasarkan data dari website Himpunan Pramuwisata Indonesia (HPI) https://dpphpi.org telah terdata ada sebanyak 8138 anggota resmi dan tersertifikasi dari HPI yang tersebar di seluruh provinsi di Indonesia dengan diorganisir oleh pihak DPD (Dewan Pimpinan Daerah) HPI masing - masing provinsi, dan kemungkinan besar masih ada banyak sekali pramuwisata resmi lain yang belum tercantum datanya di website HPI tersebut. Oleh karena itu, Indonesia bisa dikatakan memiliki banyak sekali pramuwisata yang memiliki profesional, sehingga dalam penyelenggaraan event internasional seperti MICE Indonesia tidak terlalu khawatir dengan penyediaan pranuwisatanya 


\section{Jasa Pengeelola Event Internasional dan MICE}

Indonesia saat ini telah memiliki organisasi yang berfokus pada bidang penyelenggaraan event MICE yaitu ASPERAPI (Asosiasi Perusahaan Penyelenggara Pameran dan Konvensi Indonesia) atau Indonesain Exhibition and Convention Organizer (IECA). Saat ini Asperapi telah memiliki banyak anggota atau member perusahaan penyelenggara pameran dan konvensi yang tersebar di seluruh Indonesia, berdasarkan data yang dihimpun dari official website Asperapi di

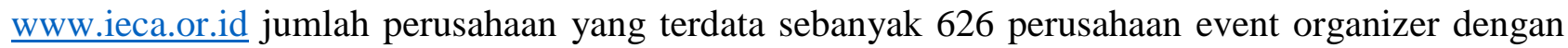
reputasi baik yang tersebar di seluruh Indonesia, dengan banyaknya perusahaan profesional dibidang penyelenggaraan event MICE tersebut, Indonesia tidak perlu khawatir untuk menentukan perusahaan mana yang akan ditunjuk nantinya.

\section{PENUTUP}

\section{Kesimpulan}

Industri MICE sangat potensial dan bermanfaat bagi pariwisata Indonesia di antaranya: (a) berkontribusi terhadap penciptaan lapangan kerja, (b) peningkatan pendapatan daerah dan devisa negara, (c) memberikan dampak keuntungan bagi bidang: percetakan, hotel, perusahaan souvenir, biro perjalanan wisata, transportasi, professional conference organizer (PCO), usaha kecil dan menengah (UKM), dan event organizer.

Selain infrastruktur dan daya tarik wisata, Indonesia juga memiliki banyak sumber daya manusia yang berkualitas dan berkompeten dalam menyelenggarakan international event seperti MICE hal tersebut terbukti dengan banyaknya organisasi atau asosiasi jasa pelayanan dan pengelolaan pariwisata yang tersebar di seluruh Indonesia seperti ASITA, Asperapi, PHRI, APJI, HPI, PUTRI, Gahawistri, ASPINDO, HPP, AKPI, MPI, dan HHRMA yang siap untuk menyediakan dan mengelola bisnis MICE di Indonesia.

Event MICE yang diselenggarakan di Indonesia dapat memberikan banyak dampak berupa keuntungan tersendiri bagi kemajuan industri pariwisata Indonesia mengingat terdapat berbagai potensi bisnis yang mendapat keuntungan besar dari Industri MICE, mulai dari percetakan, hotel, perusahaan souvenir, biro perjalanan wisata, transportasi, professional conference organizer (PCO), usaha kecil dan menengah (UKM), gedung pertemuan, sarana dan prasarana infrastruktur, jaringan komunikasi dan berbagai tourist attractions.

\section{Saran}

Indonesia sangat berpotensi dalam pengembangan kota MICE terutama telah didukung oleh falisitas hotel, Food and Beverage Service, Entertainment, Shopping, daya tarik wisata dan lain sebagainya, namun pihak pemerintah pusat dan daerah perlu untuk segera memfokuskan dan 
merealisasikan penataan infrastruktur, transportasi dan Tourist Attractions yang semakin menarik, berkualitas dan bertaraf internasional. Diharapkan adanya kegiatan promosi dan pengenalan potensi industri MICE di daerah - daerah seluruh Indonesia, sehingga akan membantu terselenggaranya kegiatan MICE dan terciptanya icon sebagai "Surga MICE Dunia". Perlu adanya peningkatan kapasitas pemenuhan SDM yang handal dalam pengelolaan MICE dengan memberikan pelatihan yang intensif bagi para pelaku wisata di seluruh Indonesia

\section{DAFTAR PUSTAKA}

Andiani, Nyoman Dini. (2014). Pengelolaan Wisata Konvensi. Yogyakarta: Graha Ilmu.

Dwyer, L., Mellor, R., Mistilis N., Muler, T. (2000). Forescasting the Economic Impacts of Events and Convention. Event Management 2000, 6 (1), 192-204, diambil dari https://doi.org/10.0000/096020197390266

Gopinath, Senthil. (2019). ICCA Statistics Report Country\& City Rankings Public Abstract: The International Association Meeting Market 2018, diakses di laman http://www.iccaworld.org Laporan Akuntabilitas Kinerja. (2018). Jakarta: Kementerian Pariwisata Republik Indonesia Montgomery, R.J \& Strick, S.K. (1995). Meetings, conventions, and expositions-An introduction to the industry. New York : Van Nostrand Reinhold.

Pendit S. Nyoman. (1999). Wisata Konvensi, Potensi Gede Bisnis Besar. Jakarta: PT. Gramedia Pustaka

Statistik Hotel dan Akomodasi Lainnya. (2018). Jakarta: Badan Pusat Statistik Indonesia

Undang-Undang No. 10 tahun 2009 tentang Kepariwisataan Oka A. Yoeti. 2000. Manajemen Wisata Konvensi. Jakarta. Pertja

World Tourism Organization. 2006. Measuring The Economic Importance of The Meeting Industry: Developing a Tourism Satellite Account Extension. Madrid: UNWTO

Yoeti, Oka, Drs. MBA. 2000. Manajemen Wisata Konvensi. Jakarta: PT. Pertja

Sumber Lain:

1. www.icea.or.id diakses pada tanggal 25 Agustus 2019

2. www.kemenpar.go,id/post/indonesia-convention-exhibition-bureau. diakses pada tanggal 24 Agustus 2019

3. https://dpphpi.org diakses pada tanggal 24 Agustus 2019

4. https://www.apji.id.id_ID/ diakses pada tanggal 24 Agustus 2019

5. https://www.idea.or.id/berita/detail/pasar-idea-2019-hadir-untuk-pertama-kali-di-indonesia, diakses pada tanggal 24 Agustus 2019

6. https://www.incca.id/p/about.html?m=0 diakses pada tanggal 23 Agustus 2019 
7. https://www.asita.id/ diakses pada tanggal 23 Agustus 2019

8. https://www.bps.go.id/subject/17/transportasi.html diakses tanggal 23 Agustus 2019

\section{PROFIL PENULIS}

Rr. Chusnu Syarifa Diah Kusuma, M.Si adalah seorang dosen dengan jabatan Asisten Ahli dan merupakan salah satu dosen di Jurusan Pendidikan Administrasi Fakultas Ekonomi Universitas Negeri Yogyakarta. Memiliki latar belakang pendidikan S1 Administrasi Bisnis dan S2 Ilmu administrasi dengan konsentrasi admininistrasi Bisnis Universitas Diponegoro. Beberapa artikel yang dihasilkan diantaranya "Pentingya Guru Dlam Pengembangan Minat Belajar Bahasa Inggris" dipublikasikan dalam jurnal efisiensi-kajian ilmu administrasi 13(2), 66-84 N. Efisiensi Vol. XIII No. 2. Agustus 2015. Selanjutnya tulisan berjudul "Integrasi Bahasa Inggris dalam Proses Pembelajaran", dipublikasikan dalam jurnal efisiensi-kajian ilmu administrasi Edisi Agustus 2018 Vol XV No.2. Tulisan lainnya berjudul "Counteract Hoax Through Reading Interest Motivation" dipublikasikan dalam International Journal of Business Quantitative Economics and Applied Management Research (IJBEMR) Vol 4, issue 3 August 2017, ISSN 2349-567 